\title{
Introducción:
}

\section{Construir estrategias para nombrar (otra vez) lo prohibido}

\author{
Coordinadora Monográfico 135 \\ Florencia CREMONA \\ Universidad Nacional de La Plata, Argentina / cremona23@yahoo.com
}

Cada vez que se reconfiguran los gobiernos conservadores, el control de las mujeres se vuelve a imponer como verdad natural. Sin embargo, caeríamos en la trampa de las corporaciones mediáticas si redujéramos el género a las mujeres y la emancipación a la violencia. La típica estrategia para sacar al género y las sexualidades de agenda es alisar su carga política en la llanura de lo temático. Género: tema de mujeres, gays, trans, lesbianas, femicidio, reparto inequitativo de las ganancias, aborto, etc. De ese modo para el gran público, que creció toda la vida en la norma heterosexual e incluso aceptándola como modo natural de vivir la vida, es difícil asociar el triunfo electoral de Trump como presidente de los Estados Unidos con una contraofensiva del patriarcado temeroso ante su pérdida de "derechos habituales".

Las investigaciones que se presentan en este número de Chasqui demuestran, una palabra tal vez poco apropiada, que se trata de todo lo contrario a reducir el patriarcado a la violencia contra las mujeres y la amplia diáspora de sexualidades que no alcanzan los objetivos por lo femenino o lo masculino tradicional.

La violencia estructural contra las mujeres es el modo de hacer perdurable al patriarcado.

Violencia que no es solo la simbólica o la que encuentra su final más cruento en el femicidio, sino en la depredación de las fuerzas de seguridad, la legitimidad del orden y el control, el pánico frente a lo diferente y al caos emocional que podría generar un gobierno feminista.

De modo que para mantener el estado de las cosas es necesario reponer los valores con los que se crearon las naciones y nuestros estados latinoamericanos colonizados: la idea del mérito, del merecimiento, de la supervivencia del más apto, del amor como relato de dominio, la autoayuda como respuesta evasiva a las injusticia o el disciplinamiento religioso. Dichas prácticas tienen en común la clasificación de los cuerpos feminizados como cuerpos otros, como cuerpos que, recreando a Rita Segato, deben probar su decencia para merecer la vida. 


\section{Comunicación y Género una alianza poderosa}

Mantener los rasgos de inteligibilidad del patriarcado es un plan sistemático e indispensable de la estrategia permanente de comunicación y cultura de las empresas del mundo: clasificar cuerpos y usos. La agenda mediática aborda a las mujeres y a las sexualidades no hegemónicas no binarias como sinónimo de minoría, reduce el problema del gobierno del mundo a una conducta, y ubica al género como ideología de buena voluntad; algo que puede o no pensarse según las ganas individuales de los sujetos.

Como si haber ignorado durante siglos los derechos de las mujeres no haya tenido un fuerte componente ideológico. Como si la clausura de los derechos civiles, como el voto, el divorcio, (¿el aborto?) no hayan sido una mirada ideológico política de quienes estamos destinadas a lo doméstico. Aunque lo doméstico sea conducir los destinos de un país, siempre y cuando se haya accedido a ese puesto mediante alianzas conyugales o procedimientos electivos legitimados por varones que garanticen el control sobre la potencial locura que puede regir las decisiones de una mujer con mando.

Los artículos de este número de Chasqui nos confirman que no puede condensarse al género como una temática, sino que es todo lo contrario. La acumulación de sentidos contra la vida de las mujeres y las sexualidades no hegemónicas se dispensa en todas las áreas de la sensibilidad humana.

Y es desde todos esos espacios desde los que nos alentamos a producir nuevas retóricas.

¿Qué esconden y qué celebran las fiestas cuando la sexualidad entre varones se habilita como máscara de carnaval? Cuando la cultura habilita otros modos de gozar, siempre y cuando no se instalen como normales.

¿Por qué la ciencia como territorio de construcción de verdad excluye a las epistemologías de género?

La política en Brasil en tiempos de destitución de lo público carga versiones caricaturescas que abordan a Dilma Roussef, y a las mujeres políticas, como a pantomimas del error. Acaso es la política con estas reglas de juego un territorio posible ¿Cuándo vamos a haber feministas conduciendo el Estado? ¿O es que la articulación Estado-gobierno-feminismo es un oxímoron en estas tierras?

¿Qué espacios habitan las masculinidades no hegemónicas? ¿es posible construir nuevos modos de estar juntos que superen el binarismo electivo? ¿Cómo podemos reflexionar sobre las familias homoparentales y en ese desafío desmantelar toda la propuesta política económica del patriarcado que sigue viendo en la familia heterosexual la base de su futuro permanente?

¿Cómo transcurren las mujeres en las cárceles y en el ejercicio de la prostitución? ¿Es posible descolonizar la mirada de la ciencia, siendo que tiene más valor en el mercado científico una ecuación que una consigna? 
¿Hasta qué punto las dictaduras cívico-esclesiásticas-militares encontraron en la división sexual un fundamento para ejercer el control, disciplinando primero el hogar?

Los artículos nos arrojan más que nuevas y perfectibles preguntas acerca de cómo podríamos habitar el mundo. Si en cada palabra nos atrevemos a ubicarnos a nosotras mismas como piezas colocadas y rebeldes en los destinos predicativos del patriarcado. La comunicación, las empresas mediáticas se han encargado de que lo normal siempre parezca lo razonable y que lo razonable sea la verdad de la interpretación biológica y binaria del cuerpo.

Vivimos horas hostiles en las que la sangre, el dolor y la violencia, la carencia, el hambre y las soledades abrazan nuestros días. Sexualidades predictivas que ya no sacian el amor imitando las pantallas pornográficas que enseñaron a generaciones enteras a organizar sus orgasmos. Suicidios adolescentes que ya no creen en el contacto humano, depredación de cuerpos que no entran en las pequeñas tallas de las fotos. Fotos que niegan lo que queda fuera del lente; toda la mugre que se esconde para obligar la vigencia de un relato funesto: el que construye cada día el machismo cultural, la supremacía de un Hombre infinito y universal. Héroe maléfico que aúlla caprichoso como deberían ser los otros, siempre tan diferentes a sí mismos.

Son momentos para mirar el sistema político del patriarcado y la violencia machista instalada en el discurso como uno de los fundamentos principales del presente. Cada uno de estos sugerentes y muy bien trabajados artículos nos invita a reflexionar acerca de la importancia de destramar el género de la vida cotidiana para transformar la humanidad. No solo mediante leyes, sino desde la profunda creencia de que es injusto vivir como vivimos, de que merecemos rebelarnos a los confines de nuestra biología y vivir plenamente, desterrando los fantasmas y las voces que nos habitan. 